\title{
The Interpreting of Sermon At Gereja Kristus Yesus Kuta Bali
}

Ferly Rambu Dawi Ngana ${ }^{1}$, I Made Suastra ${ }^{2}$, Ida Ayu Made Puspani ${ }^{3}$

Talk2ferly@gmail.com

Udayana University, Bali, Indonesia.

\begin{abstract}
This research is a research on interpreting which focuses on one of the religious events in Gereja Kristus Yesus Kuta Bali. This Study focuses on the product of interpreter-mediated sermons on Sunday services from English into Indonesian. The study is concerned with two major problems which consist of 1) the types of interpreting adopted by the interpreters in sermon interpreting at Gereja Kristus Yesus? 2) the strategies applied by the interpreters and the impact towards to target language in sermon interpreting at Gereja Kristus Yesus? It aims at identifying and analyzing the types and strategies applied by the interpreters. The approach adopted for this study is qualitative method, in which data were taken from the texts of 2 authentic audio-video recordings of interpreter-mediated sermons. The data were collected through non-participant observation, method, supported by the implementation of the note- taking technique, and then descriptively analyzed. The theoretical framework adopted in this study was drawn from a number of theoretical models in the field of translation and interpreting studies. The first is the types of interpreting modes proposed by Pochhaker's (2004) and the Second theory is the strategies of interpreting proposed by Nolan (2005) . The results of this study shows that the mode of interpreting adopted by the interpreters is consecutive interpreting. Especially short-consecutive interpreting mode.
\end{abstract}

Keywords; interpreting; sermon; technique; equivalence. 


\section{Introduction}

Language is considered as the most important part of human's life because it is used by all people in their social life to express their experience. Halliday (1980) in but at all (2012:258) defined language as the key instrument used by people to interpret and organize their experience. Language as communication tool very important and be a part of any human activity that involves all aspects of community such cultural, political, economic, religious, etc.

Based on the background of study the aimed of this study is to investigate the interpreting types and strategies applied by the interpreter at 'Gereja Kristus Yesus Kuta Bali' and there are two problems as formulated:

1. What are the types of interpreting applied by the interpreter in interpreting the sermon at Gereja Kristus Yesus Kuta Bali?

2. What are the strategies of interpreting applied by the interpreter in interpreting the sermon at Gereja Kristus Yesus Kuta Bali?

\section{Theoretical Framework}

A. Interpreting Types

The types of interpreting can be based on the modes and the setting of interpreting. The modes of interpreting refer to the way in which interpreting is offered and the setting refers to where the interpreting takes place. There are some types of interpreting in general refer to the way or the production of the source message in relation to its delivery in target language. The types of interpreter are classified variously. Pöchhaker (2004: 18-20) distinguished five types of interpreting that are commonly used. Those types of interpreting are as Simultaneous Interpreting. According to Pöchhaker (2004: 18-20) simultaneous interpreting refers to the mode interpreting in which an interpreter delivered the speech message after the source-language utterance in other words the rendering is conducted almost at the same time as the flow of the utterances from the speaker to the interpreter at the same place of time renders the message of the utterances of the speaker to the hearers. Mostly, simultaneous interpreting is delivered in the International conference where the interpreter stays behind the booth while she/he renders the message of the source language to the target language. Consecutive interpreting In consecutive interpreting, the utterances of the speaker maybe uttered in certain place of time when the speaker makes a pause then the interpreter starts to interpret the message of the source language to the target language or this type of mode is conducted based on the needs of the user (client). The differences between simultaneous and consecutive interpretation is on the amount of time elapsing between the delivery of the source utterances and the delivery of the interpretation. Whispered interpreting. Pochhacker 2004:19) stated whispered interpreting also known by the French term as 'chuchotage' or whispering is a mode of interpreting done by whispering but it does not mean the interpreter working by whispering listener but it means the interpreter will be speaking in low voice. For instance, the tour guide who wears a headset in handling guest. In addition, it is deals with voice source, this mode can be done by using equipment such as microphone and headset. Sight interpreting Pochhacker $2004: 19$ sight interpreting could be labeled more correctly as 'sight interpreting' is a variant of simultaneous interpreting. It is described as the rendering of 
material written in one language into spoken speech in another language. This mode is a variant of simultaneous mode. Sometimes the use of a sign interpreting served as the native speaker for the deaf as a group which is own cultural identity. Liason Interpreting Pöchhacker 2004 :14 states that the liaison interpreter as a form of interpreting practiced mainly in commercial negotiations, which uses two languages to interpret for two or more people. In addition, it can be said liaison interpreting is a process of connecting and linking up two people who does not speak same language in spontaneous conversation setting.

\section{B. Interpreting strategies}

Nolan (2005) recommend more generally on the strategies of on interpreting as follow:

1) Preparation/ Anticipating the Speaker

In preparation, the interpreter must acquire a perspective of having a desire to learn, continue with differences in his or her localized language as well as being able to interpret the material to fit the occasion. Interpreter must be able to comprehend and obviously be competent to communicate a wide spread of points and statements given to explain a belief or act to speak both sides of any subject or problem that people are thinking and talking about to provide something, even a disagreement which may seem unbelievable, or with which they may strongly disagree with.

Example:

Speaker : It is a great____ to represent Canada here today as we celebrate the fiftieth anniversary of the United Nations during this general debate.

Interpreter: Alors que nous célébrons le cinquantième anniversaire des Nations Unies durantce débat général, c'est un insigne pour moi de représenter le Canada

aujourd'hui dans cette enceinte. (Nolan 2005:21)

From the example above there are times when "words fail". But an interpreter does not have the time to break, and think of some other word. These times, one of the easy ways out is to communicate the main information of the intentional message is not to the other words but through tone.

2) Complex Syntax/compression

Nolan stressed that when speakers use brief, analytical term and speak at average often quickly, the interpreter's undertaking is made easier. More complex sentences can also be interpreted without too much trouble if spoken at quickly average. However, when speakers use extended, compound forms deliver them at fast moving, the interpreter's duty is greatly complex. For example in the used of conjunction. Position of ambivalent conjunctions at the beginning of the sentences can create troubles in interpretation. When the wrong meaning to the conjunction set down by the interpreter, the interpretation result of the rest sentences can be misunderstood or turn out inaccurate.

3) Word Order/ Cluster

When translating and interpreting, it is crucial to keep away from automatically imitate the word sequence and structure of the source language. The words of the source language must be accepted, and the sentences must be perceived. The meaningful form with which translators and interpreters deal are not words or the sentences. It is significant to observe part of definition by sweep a discourse as to hear clauses or clusters of words that can be translated into similar clusters in the target language. 
There are two kinds of clusters as follow:

1. Noun + adjective clusters

Noun + adjective cluster must be dealt with as units because adjectives in different language fall into different sequences in a noun phrases.

For example,

English: big black dog

French: grand chien noir

Based on the example above when a number of adjectives are used together, the sequence depends on the use of adjective. the adjective of size "big" must go before the adjective of color "black" so must be ("big black dog", not "black big dog"), compared in French the adjective of size goes before the noun and the adjective of color comes along behind ("grand chien noir", not "grand noir chien"). (Nolan 2005:46)

\section{Verb Object cluster}

The usage of Verb object clusters need to be concerned with as elements because, some verbs will not work with some objects and the other way around.

For example,

a) English : to succeed

French : aboutir a une conclusion heurese

b) English : To clarify our proposal

French :facilitar la comprension de neuestra propuesta. Nolan (2005:45)

Based on the example sentences above concerning cluster as single components of meaning will also help to point out those occurrences where to express in a shorter form of wordiness by translating few words with one, which is especially useful in interpreting a brief speech. The best way to identify these cases is to 'listen for descriptions' and then use the word related to the definition that has just been heard and to express more fully and in capacity, the interpreter should look in dictionaries and practice crossword puzzles or riddles.

4) General Adverbial Clauses

A general adverbial clause magnifies the main verb in the word group expressing statement. The clause can modify or describe verbs, adverbs and adjectives. The function of a general adverbial clause is an adverb in a sentences, often to add information. This strategy usually is used by the interpreter to set the section for the rest of the sentences.

For example:

Original structure: Let us take a look at this experience and potential in those areas which, as is widely recognized and attested to even by this current debate, have become very important for preserving world peace and security.

Official English version: Let us take a look at this experience and potential in those areas which have become very important for preserving global peace and security, as is widely recognized and attested to even by this current debate. (Nolan 2005:53) 
The example above the basic subject-complement structure of the sentences is 'areas are becoming" and in English the general adverbial clause in bold type could go before the verb, or after the verb, or even at the end of the sentence, as has been done in the official version. (Nolan 2005:53)

\section{5) Untranslability}

Nolan admitters Untransalabity occurs when it is not able to have its sense satisfactory in another language, there often are idiomatic expressions to the saying. No matter how superior the translation, something seems to be untranslated or interpreted on every occasion. It is that "untranslatable" remain of definition that cannot be conveyed out in the target language which is open to some linguists to acknowledge that in a conceptual perception translation unachievable in target language.

For example, in English: Ouch (feeling pain when hitting a thumb with hammer) Nolan (2012:55)

\section{6) Figures of Speech}

Translators and interpreters should be paying attention to figurative language of source text and need to master a figure of speech in target language. Figure of speech refers to a form of expression used to convey meaning by comparing one thing with another. Words are sometimes having connotation form units of meaning in ways that convey more than the rules of grammar dictate Such as idiom, simile, metaphor, proverb.

Example: Don't throw out the baby with the bath water (Nolan: 2012:64)

\section{7) Argumentation}

Every time the interpreter faced with technical material. (Nolan,2005:117) states the interpreters are responsible to develop some acknowledgement of both analytical and emotive speaking. In this case the interpreter is giving a set of "statement or reason" about something to convince others, and relies on important logic or a strong feeling. An interpreter must be ready to deal to source language and target language and keep an image in their memory that they are not mutually to be only used by one particular person. A logical given reason can be elaborated or made more convincing by an imaginative use of words. If a speaker's sense is wrong, the interpreter's tone must not go against the illogicality. And if the speaker develops tuneful to a degree that the interpreter finds unbelievable, the interpreter's intonation must not go against his uncertainty.

\section{8) Diction/ Register}

Sometimes the interpreter intuition depends on the speaker tone. Nolan (2007:121) describes that tone of voice can be used to give the conversation color and more vibrant. Generally, the interpreter must observe the forms of political truth instructed by the forum and the convenience, whenever in doubt choosing balance. However, strong language is not on the whole missing, and words are often used which carry dictatorial moral judgments. Especially common for Words, of moral disapproval of admonition.

9) Formal Style

Nolan (2012: 163) states that choice of words of a speaker must satisfy three criteria: they must be appropriate to the subject, the occasion, and the audience. This of course, applies with equal force to the writer's translator or to the speaker's echo, and must reflect the speaker's sense of occasion, and the more important the occasion, the more accurate and complex should be the reflection. 
10) A Policy Address

Nolan (2005:191) explained that a policy address is an official public statement of position, for the record. Such an address is usually delivered by a plenipotentiary ambassador, a foreign minister, or the head of state or government. Consequently, as regards the content, nearly perfect accuracy is required. Each and every idea must be correctly rendered.

\section{1) Transposition}

Nolan (2005:207) arguments that transposition strategy is a process where words are replaced with another without changing the meaning or message but parts of the speech change their sequence when they are translated or change the grammatical shift of word class. The easy way convey such a complex message is that the interpreter opts for transposition: looking for approximately equivalent reference drawn from English literature.

For example: 'Evil incarnate' from the wizard of oz to to convey this idea and translated as follow: we should not treat our opponents here as the Wicked Witch of the West. Nolan 2005:207

13) Economic Discourse

In economic representation the translator and interpreters must master good basic vocabulary relating to it. Furthermore, Nolan (2012:225) explained that the translation and interpretation of writing and oral presentations on economics can be very scientific. Much of the vocabulary of business and economic commentary consists of technical terms.

For example: -demand elasticity

$$
\text { -sluggish market }
$$

Based on the example above in international presentations generally include a good deal of economic terms, often as the basis of or justify cation for a statement of position or policy argument. Translators and interpreters must therefore have at their fingertips a good basic vocabulary for economic description.

\section{4) Humor}

Many speakers sometimes in deliver the speech include a humorous just to be clever or simply to establish rapport with the audience, in this case Nolan said that humor is difficult to translate and even more difficult to interpret. For an interpreter to draw a laugh from the audience at the same time that those hearing the original joke burst into laughter is rare feat. An interpreter must be attentive to the purpose of the humor if not lost of translation will happening.

Example:

Speaker: Mr. President, I have made so many concessions on this resolution that I feel I am sticking my neck out.

President: Well, I will do all I can to make sure it doesn't get chopped off. (Laughter)

French interpreter: Je ferai de mon mieux pour que vous ne soyez pasdecapitel

(laughter) Nolan (2011:247)

\section{5). Numbers}

It is very important to pay attention to the numerical concept. Nolan (2005: 288) explained that figures given by speakers are generally offered either as an order of magnitude or as a technical 
measurement. It is important to distinguish these because an interpreter has considerable leeway in rendering the former and very little way with the latter.

For example, if the figure $25.8 \%$ is offered as an order of magnitude, and interpreter having trouble with speed can simply "roughly quarter". However, if the figure, "259.6 milligrams" were given in a statement to an audience of pharmacologists.

\section{Methods}

The sequence of data analysis then will arrange into the following ways: Firstly, each conversation that will be transcribe into written text is analyze in terms of the mode and the setting of the interpreting being used by the interpreter at Gereja Kristus Bali. Secondly, both data in SL (English) and TL (Indonesian) will put one after another to make it easier to conduct the comparative analysis. The data will classify into some procedures in translation and will analyze from semantic and pragmatic point of view. The aim is to evaluate the data before they analyze with entire framework

\section{Finding and discussion}

This section would be examined two matters related to the problems of the study. First, what are the types of sermon interpreting applied by the interpreters in interpreting the sermon at Gereja Kristus Yesus Kuta. Second, it deals with strategies of interpreters applied by the interpreter in interpreting the sermon at Gereja Kristus Yesus Kuta . Furthermore, they would be explained as follows.

\subsection{Types of Interpreting}

Analysis of the Modes of Interpreting applied by the interpreters in interpreting the sermon at Gereja Kristus Yesus divided into the analysis of the mode and the setting of interpreting. The mode of interpreting refers to how the interpreting was done by the interpreter and the setting of interpreting refers to where the interpreting took place.

From the theory of the modes proposed by Pochacker (2004) there is one modes of interpreting: simultaneous, consecutive, whispered, sight and liaison interpreting. In this writing the mode of interpreting conducted by the interpreter in Gereja Kristus Yesus was consecutive mode because in the sermon, the interpreter used some characteristics contained only in consecutive mode. The analysis of the mode as follow:

SL : Heavenly Father, we thank you for this wonderful time you have given to be together as the body of Christ.

TL : :Kami mengucap syukur Tuhan untuk waktu ini kami boleh berkumpul bersama

SL : And Lord we want to lift up this time that you would anoint us by the Holy Spirit in sharing the word of God and translating it.

TL : Dan anugerahkan hati ini dan engkau mengurapinya hamba Tuhan dalam pengerjaan khotbah

The above utterances were some examples of conversation which were selected along the sermon service at Gereja Kristus Yesus Kuta Bali. Based on the characteristics the interpreter started to interpret after the speech delivery by the speaker in short time. The interpreter did the interpretation at the interval of each speech delivery uttered by the speaker which consists of phrases or even short sentences as shown on the above example. 
The process of consecutive interpreting at Gereja Kristus Yesus was considered as the short consecutive interpreting where the interpreter relied on memory, because each segment of utterance was brief enough to memorize by the interpreter. As we see from the data above, the speaker did not utter the long sentences but only short and simple utterances, allowing for the enough time for the interpreter to interpret so the interpreter could directly have transferred the meaning in target language to the audience. This kind of utterance did not require the interpreter to take notes.

In this writing the mode of interpreting conducted by the interpreter in Gereja Kristus Yesus Kuta Bali was consecutive mode because in the sermon, the interpreter used some characteristics contained only in consecutive mode. The analysis of the mode of interpreting as follows:

1. The Interpreter Speaks after the Source-Language Speaker has finished Speaking Data 1, Sermon 2

PR : Let's pray together

INT : Mari kita berdoa bersama

PR : Our Lord we just thank you so much for this time you given to us to be Together as the body of Christ

INT : Bapa kami sungguh berterima kasih bapa untuk waktu ini kami dapat berkum pul bersama sebagai satu tubuh kristus

The data above utterances were some examples of conversation which were selected along the sermon service in Gereja Kristus Yesus. The interpreter started to interpret after the speech delivery by the speaker, consists of phrases or even short sentence by sentence basis as shown on the above examples.

One of the example taken from utterances above: "Pray for your two servants that are full of limitations "and interpreted "Berdoa untuk kedua hamba Tuhan ini yang penuh dengan kelemahan". Based on the example after the speaker finished his utterance, then the interpreter started to interpret in Indonesian as the target language to the congregation in the sermon service.

\section{Length of a Sermon}

In the Church in which sermons are analyzed in this study, a sermon takes around 30-40 minutes with its interpretation while the Length of the Speech Segment is Short. The process of interpreting was considered as the short consecutive interpreting where the interpreter relied on memory, because each segment of utterance was brief enough to memorize by the interpreter. As we see from the previous data, the speaker did not utter long sentences but only short and simple utterances.

3. Rely on the Text Structure

The above utterance were some examples of conversation which were selected along the sermon service. Based on the characteristics of consecutive interpreting, the interpreter delivers the speech of the speaker, usually sentence by sentence basis. The interpreter did the interpretation at the interval of each speech delivery uttered by the speaker which consist of phrases or even short sentences as shown the above example.

4. Without Systematic Note-Taking 
Note taking is very useful for future reference especially if he/she get the change to look at the presentation before it is delivered. As stated by Baker 1992:278 it is good to learn the art of summarizing to help with translation later when the words are being presented. Note taking also useful in consecutive interpreting when short term memory loss occurs. In the interpreting the sermon at Gereja Kristus Yesus Kuta the interpreter never took notes as presented the data below.

PR : Let's pray together

INT : Mari kita berdoa bersama

PR : Our Lord we just thank you so much for this time you given to us to be together as the body of Christ

INT $\quad$ : Bapa kami sungguh berterima kasih bapa untuk waktu ini kami dapat berkumpul bersama sebagai satu tubuh kristus

PR : And Lord we lift up this time to you to study your words you speak to our heart teaching individually

INT : Bapa kami serahkan waktu ini kepada-Mu Bapa kiranya engkau berbicara bapa kepada setiap diri kami bapa

From the data above the interpreter directly interprets after the speaker finishes his speaking. The interpreter never took notes because he uses their memory only. He or she maybe study the presentation before and make notes to refresh his memory before the event. But when the presentation the interpreter is aware of the material and can use his memory to render the translation correctly.

5. The Setting of Interpreting

Analysis the setting of interpreting is based on where the interpreting takes place. The data was taken from the Sermon at Gereja Kristus Yesus Kuta Bali. In this case study of interpreting which was performed by the American priest who took a role as a priest and Indonesian who took the role as an interpreter in the sermon. Based on the research, this kind of interpreting which took place at public place for great number of the community can be considered similar to the kind of community interpreting. The setting describes the qualities of the immediate setting in which the issue at hand is investigated, from general to more specific. With this aim in mind, an actual interpreting event representative of a typical Sunday service was Audio recording.

6. Description of the sample event

The video was recorded with the permission of church leaders but without the knowledge of the English consecutive interpreter, a member of the congregation. Recording videos was a regular practice of the church to keep a record of Sunday services such as this one, therefore the preacher and interpreter knew they were being recorded, but they were not informed that the recording would be used for research purposes. Because the visiting preacher was not fluent in Indonesian, he preached in English, and the sermon was consecutively interpreted into Indonesian from the front. Here is the sequence of events for a typical Sunday church service at Gereja Kristus Yesus, based on the video recording of the service on May 19, 2019 January 12, 2010. and February 21,2020. 


\subsection{Strategies of Interpreting applied by the Interpreter in Sermon Interpreting at Gereja Kristus Yesus Kuta Bali}

The techniques in interpreting applied by the interpreter in Gereja Kristus Yesus covers out eleven techniques proposed by (Nolan 2005). The kinds of strategies applied by the interpreter, according to my research consist of ten techniques out from sixteen strategies proposed by Nolan (2005) there are preparation the speaker, complex syntax/compression, word order/cluster, untranslability, figures of speech, Argumentation, transposition, economic discourse, humor, and numbers. The data below consists of selected utterances uttered by the speaker in Source Language (English) and interpreted by the interpreter in Target Language (Indonesian) The analyses of strategies that were applied by the interpreter are presented descriptively as follows

1. Preparation the speaker

The Interpreter should be able to understand and clearly state a wide range of possible ideas and arguments representing different sides of any issue conveyed by the speaker.

The following data is drawn from sermon 1 . In this sequence, the preacher had just start the sermon by opening prayer as preparing the congregation. The interpreter was then delivered the message directly to the congregation in TL immediately after the preacher paused or completed each of his utterances.

From sermon 1, page 1

1)PR : Heavenly Father, we thank you for this wonderful time you have given to be together as the body

of Christ.

2)INT : Kami mengucap syukur Tuhan untuk waktu ini kami boleh berkumpul bersama

3)PR : And Lord we want to lift up this time that you would anoint us by the Holy Spirit in sharing the word of God and translating it

4)INT : Dan anugerahkan hati ini dan engkau mengurapinya hamba Tuhan dalam pengerjaan Khotbah

5)PR : Pray for your two servants that are full of limitations

6)INT : Berdoa untuk kedua hamba Tuhan ini yang penuh dengan kelemahan

The excerpt above shown that the preacher observed the preparation, in which the preacher prepared the sermon by ask the guiding of the holy spirit. As we can see, the preacher said "we want to lift up this time that you would anoint us by the Holy Spirit in sharing the word of God and translating it" and it was rendered by the interpreter into "Dan anugerahkan hati ini dan engkau mengurapinya hamba Tuhan dalam pengerjaan Khotbah." Based on the example the preacher applied the preparation strategies in source language and directly the result of the TL is the interpreter asked the holy spirit to guide in sharing the word of God. We can see the strategies proposed by Nolan (2005:17). In this case the preacher and the interpreter must maintain attention and concentration on the theme of the Sermon.

\section{Complex Syntax/Compression}


In interpreting a speech, especially a fast speech, good strategy breaking up any long sentences into shorter ones, identifying whole ideas or units of meaning and clarifying the relationship between the sentences. This technique of complex syntax was used in order to compress the wording of the originally of the source language. The data of complex syntax/ Compression as follows:

Sermon 2 page 8

PR : Because he is the leader he is the shaper, he is the pastor, he is the priest over the family the responsibly for them to priest, to make money and to take them care spiritually.

INT : Karena Laki-laki dalah pemimpin gembala imam untuk keluarganya

Based on the data above, the interpreter rendered the rendition immediately behind the speaker's utterances after that listening the next utterance to interpret consecutively. The SL utterances above basically was a complex sentence which has a simple form of "Because he is the leader he is the shaper, he is the pastor, he is the priest over the family the responsibly for them to priest make to make money and to take them care spiritually" the interpreter compress the sentences into a clause in the target language "Karena Laki-laki dalah pemimpin gembala imam untuk keluarganya" due to the complex expression used by speaker. To save time, the interpreter deleted the next information.

\section{Word order/Cluster}

It is very important as it is differing in many language, the interpreter quickly to identify units of meaning by scanning the speech into phrases or cluster of words into target language. The word order/cluster was used efficiently to save time when the speaker delivered his utterance very fast. The following expert is drawn from sermon 2 related to word order/ cluster as follow:

Sermon 2 page 6

1.PR : and the text tonight is the command from God is to obey obey and honor our parents.

2.INT : dan dari aaa ayat Alkitab malam ini diajarin untuk menghormati ayah dan ibu

3.PR : Many of us are children here. All of us are children here (pointing) and some are under 18 and wonderful remaja and pemuda over 18. But there's a lot of you that are older but you still have parents.

4. INT : Dan kita semua di sini adalah anak anak ada juga yang dibawah 18 tahun dan remaja tapi kita semua adalah anak- anak.

In the sequence above, the preacher was talking about the function of Churches in Indonesia. The message spoken by the speaker was then delivered by the interpreter into target language. As we can see the excerpt above shows that the interpreter identifies units of meaning by scanning a speech as he hears for clusters of words that he can be interpreted into corresponding clusters of words in the target language.

The preacher's utterance in turn 1 above is consists of phrases of words, the preacher said "and the text tonight is the command from God is to obey obey and honor our parents" which was then rendered by the interpreter in turn 2 into "dan dari aaa ayat Alkitab malam ini diajarin " preacher's utterance in turn 1 above consisting of a conjunction (and), Noun (the text), adverbial (tonight), predicate (is) Noun (the command), adverbial (from God) and then it was rendered in turn 2 by the interpreter into "dan dari aaa ayat Alkitab malam ini diajarin" consisting of a conjunction (and), (adverbial) Noun (ayat-ayat Alkitab), adverbial (malam ini). Therefore, by comparing the interpreter's 
rendition in turn 2 above there are some changes in the rank of words of cluster. The interpreter avoids automatically following the word order and structure of the source language when interpreting. It can be stated that the interpreter's rendition above is close to words order, with the adjustment in the form of noun+ adverbial. Next, in turn 3, the preacher said "Many of us are children here" which was rendered by the interpreter in turn 4 into "Dan kita semua di sini adalah anak anak" The preacher's utterance in turn 4 above is consist of word order consisting of adverbial (many of), Noun (us), verb(are) noun (children),adverbial (here) and then it was rendered by the interpreter in turn 4 into "Dan kita semua di sini adalah anak anak"made of a conjunction (and), noun (kita semua), adverbial (disini), verb (adalah) noun (anak-anak). Therefore, by comparing the interpreter's strategies I turn 4 above, it can be stated that the interpreter's strategies are to avoid following order and structure of the source language and must be organized the changes of the rank or word cluster: a word to a phrase, there are different word class forms to make the product of interpreting sound more stylistic and understood as proposed by Nolan (2005:44)

4. General adverbial Clauses

A general adverbial clause modifies clause modifies the main verb in the sentence. It is often used to set the scene for the rest of the sentences (Nolan 2005: 53) When faced with very fast speaker and in order to save time, a number of specific item mentioned can be expressed in one generic term. The following excerpt is drawn from sermon 2. In this sequence, the preacher was talking about one illustration relating to the sermon. This message was then delivered by the interpreter to the congregation in TL immediately after the preacher paused or completed each of his utterances.

Sermon 2 page 2

PR : And I saw porridge with rice

INT : Ada menu bubur dan nasi

PR : And we were laughing

INT : Kami tertawa

PR : Because in Indonesia if you going to have porridge we have porridge for breakfast if we are sick and usually we rice as main menu ingredient,

INT : Di indonesia kita makan bubur untuk sarapan atau sakit-sakit dan nasi adalah untuk main menu utamanya

The utterance above is interpreted into the target language by using general adverbial clauses strategies. The interpreter used more general or neutral term. Rice could be padi, beras,nasi this technique changes particular information from SLT into general information. The utterance above word rice (beras) is generalized in TL to be nasi.

For instance, word 'rice' is rice but in Indonesian it has many names. In English the word 'rice' is a specific meaning which transforms from particular form in English (rice) into general form in Indonesia (padi, beras, nasi) which is general meaning. Therefore, the SLT can be classified into generalization technique.

\section{Untranslability}

Nolan admitters that there is a grain truth to the proverb. No matter how good the translation, something always occurs that a word or phrase cannot be translated. It is that "untranslatable" meaning 
that cannot be brought out into the target language which leads some translators to state that in theoretical sense the translation Impossible as stated Nolan (2005:57). The following excerpt is drawn in sermon 2. In this sequence, the preacher was talking about his experience when he and his family went to discovery mall. The interpreter delivered the message conveyed by the speaker to the congregation in TL immediately.

Sermon 2 page 2

1PR : Aah beloved the other day I was with my wife and daughter we went to discovery mall

2INT $\quad$ : Saudara kemarin saya dan istri saya sempat pergi ke mall discovery

3PR : And I saw on the menu of Chinese restaurant there

4INT : Dan saya melihat menu di restoran Chinese

Based on the example above, the interpreter must adopt untransbility techniques as proposed by Nolan (2005: 57) The words "discovery mall" in SL was not able to be interpreted by the interpreter into TL. So the Interpreter must use his imagination and experience to pick suitable alternative words "mall discovery" into TL because it seemed impossible to directly interpreted into TL.

\section{Figures of Speech}

Words are often used to form units of meaning in ways that convey more than the rules of grammar dictate. Such combinations or clusters of words are used deliberately because they are more the sum of their parts and thus serve as a kind of shorthand, which makes them especially useful to interpreters. Translators and interpreters must be alert to figurative language and remember that a figure of speech in another language, e.g. a metaphor by a proverb, or by non- figurative language. (Nolan: 2005:67)

\section{Sermon 2 page 12}

1.PR : And also to be homemakers and to be obedient to their husbands

2.INT : Dan untuk menjaga rumah dan untuk taat kepada suaminya

3.PR : In the world we live in today aaah the housewife its look down upon

4.INT : Di keaadan social kita sekarang, ibu rumah tangga dipandang sebelah mata

5.PR : But I believe the highest calling for woman is to be a homemaker to raise the children to the Lord

6.INT : Tapi untuk saya pribadi aa panggilan terbesar untuk wanita itu adalah untuk menjaga rumah me ngurus anak dari kecil menjaga mereka hingga besar.

Based on the example above, as home makers (husband and wife) in some cultures the wife is expected to be obedient to their husband but in this modern world the husband and wife are equal partner. The sentences "look down upon" which interpreted into "dipandang sebelah mata" consist of idiom as proposed by Nolan (2005). As we see the speaker uses an idiom therefore the interpreter not interpreted it as literally but he gets the ideas how to interpreted "look down upon" into dipandang sebelah mata" as accurately based on the context. From the context the wife is not the husband servant. It is also believed that the housewife who stays at home is a second class citzen, the words 'look down upon' as lazy because they are not employed getting a salary. But in fact the housewife works much longer hours than 
employed. The highest calling for the housewife is to raise the children so they respect their parents, others especially older people and understand and obey the laws of the country.

\section{Argumentation}

An interpreter must be alert to both and remember that they are not mutual exclusive and that neither is better. A logically sound argument can be embellished or made more compelling by a poetic choice of words, or moral argument can be stated in such powerful terms that it overwhelms all logical objections. If a speaker's logic is faulty, the interpreter's voice must not betray the absurdity. (Nolan 2005:117)

Sermon 1, page 1 .

1PR : You know it's really interesting but I didn't know about Parents' day until I came to Indonesia.

2INT : Yang menarik adalah saya tidak tahu ada yang namanya hari orang tua sejak saya datang ke Indonesia

3PR : Because outside of Indonesia, you celebrate Mother's and Father's Day.

4INT : Karena di Indonesia kita merayakan hari Ibu atau hari Bapak.

5PR : But I think that parents' day is more biblical because our parents were unified and made one before they had us.

6INT : Dan saya percaya bahwa hari orang tua itu lebih Alkitabiah karena orang tua itu diberikan sebagai 1 paket.

In the sequence above, the preacher is excited to celebrate parent's day, because usually on May many people celebrated mother's day and in June celebrated fathers. It follows that in July people bring their parents together. The speaker arguments it more biblical than what it really is. The message spoken by the speaker was then delivered by the interpreter into target language as we can see the preacher's utterance in turn 1 above said "You know it's really interesting but I didn't know about Parents' Day until I came to Indonesia" in utterance turn 2 the interpreter said "Yang menarik adalah saya tidak tahu ada yang namanya hari orang tua sejak saya datang ke Indonesia" The interpreter just follow the words based what the speaker was saying and let the congregation decide whether they agree or not because it's the job of the interpreter to just interpret and be neutral in their opinion. In untterance turn 3 the interpreter explains more the reality life in Indonesia, many people celebrate parent's day, and in utterance turn 4 the interpreter just follow the speaker logic words. In utterance turn 5, the speaker continue his argument said "But $I$ think that parents' day is more biblical because our parents were unified and made one before they had us" and interpreted by the interpreter in utterance turn 6 into TL "Dan saya percaya bahwa hari orang tua itu lebih Alkitabiah karena orang tua itu diberikan sebagai 1 paket" based the example the speaker said "But I think that" and interpreter said "saya percaya bahwa" from the interpreter statement opposite what the speaker said. The interpreter delivered it different expressive meaning, actually the interpreter supposed to interpret the word "But I think that" into "tetapi saya percaya". This is the job of interpreter just follows what the speaker said as stated by Nolan (2005:117)

8. Transposition 
Nolan (2005:215) arguments that transposition is the process where parts of the speech change their sequence when they are translated or the change of grammatical shift of word class. The data of transposition as follow:

Sermon1 page 1

PR : In Jesus' name we pray.

INT : Dalam nama Tuhan Yesus kami berdoa

The source text above is translated into the target text by using transposition technique. For instance, the word Jesus' name is interpreted into 'nama Tuhan Yesus' in Indonesia. The interpreter changed the grammatical category of the source text. There are some changes in grammatical shift and the interpreter applied when there is an opportunity to choose different word-class forms to make to product of interpretation more approximately equivalent From the previous data there is a change from phrase in the SLT to sentence in the TLT. So it can be concluded as a transposition technique.

\section{Economic Discourse}

Nolan (2005:236) sated that translators and interpreters must have a good basic vocabulary for economic description. The data relating to be analyze relating to economic discourse as follow:

Data 1 Sermon 1 page 14

1PR: There's a song I love it say "Every day is a bank account; time is our currency.

2INT :Ya dan ada lagu yang saya suka yang berkatu bahwa setiap

hari adalah rekening bank dan waktu adalah mata uangmu,

3PR : Nobody's rich, nobody's poor, we all get 24 hours.

4INT : tidak ada yang kaya dan miskin semuanya dapat $24 \mathrm{jam}$.

5PR : How are you going to spend what you invest or squander the time we get is so valuable with our family.

6INT : Waktu kita bersama keluarga sangatlah berharga.

From the data above in utterance turn 1 the speakers said in source text "There's a song I love it says "Every day is a bank account; time is our currency. Then in utterance turn 2 the interpreter rendered it into TL "Ya dan ada lagu yang saya suka yang berkata bahwa setiap hari adalah rekening bank dan waktu adalah mata uangmu. Based on the data the speaker was talking about how to manifest our time spend with our family and sang a song entitled "Every day is a bank account; time is our currency" bank account is economic terms and this is the challenge by the interpreter to master the terms relating to economic discourse. When conveyed the song the preacher sang the song title. Then the interpreter interpreted it as usually just spoke it without singing it. The words "a bank account" and time is our currency" a terms relating to the economic discourse as proposed by Nolan (2005: 235)

\section{Humor}

Humor is difficult to translate and even more difficult to interpret. For an interpreter to draw a laugh from the audience at the same time that those hearing the original joke burst into laughter is rare feat. An interpreter must be attentive to the purpose of the humor Nolan (2005:258). The following data relating to techniques applied by the interpreter when rendering utterance containing humor: 
Data 1.

Sermon 1 page 6

1PR : And sometimes you're like "Cmon dad, cmon mom, you don't know this?"

2INT : Dan kadang-kadang kita bilang ke orang kita masa gak ngerti sih?

3PR : One time a father and son were watching a soccer game.

4INT : Suatu hari aa anak dan papanya lagi nonton pertandingan sepak bola

5PR : And The son said "Look, it's Ireland against the Netherlands!"

6INT : Dan kemulian anak nya bilang lihat Irlandia melawan Belanda

7PR : And the dad said, 'It's not it's not Ireland against the Netherlands, It's Irlandia against Belanda what are you thinking?"

8PR : Dan dia bilang. aa ok (uninterpreted)

9INT :(Haha, they understood).

From the data above the speakers begin a speech on a humorous note just to be clever or simply to establish rapport with the audience. It takes skilled interpreter to instantly translate a joke and to have the audience laugh immediately. Also translation from one language to another is impossible with jokes because of differing cultural values. Some jokes also get lost in translation because of the way the translated language is structured. We can see that there was humor delivered by the speaker resulting laughter in the room. This humor was related to the illustration used about the dad and the son who have different perception. In this case, the humor conveyed by the speaker above was untranslatable. The speaker conveyed It's not it's not Ireland against the Netherlands, It's Irlandia against Belanda, what are you thinking?" in the source language with a smooth way and the speaker explained to the interpreter no need to interpret that utterance. The interpreter just passed it and continued to the next utterance which following from the speaker. In this case, the saying the speaker was clear to used target language, so without wasting time the interpreter did not render it, however, the interpreter still can render the last utterance in SL “.... Dan dia bilang. aa ok” to make a clear statement to the audience by rendering dan dia bilang aaa ok. as the alternative one.

11. Numbers

It is important to distinguish these because an interpreter has considerable leeway in rendering the former and very little way with the latter. (Nolan 2005: 288) The data of number as follows:

Sermon 1 page 3

1PR : Some people feel like they are a late getting married. They're in after their twenties and thirties still living with their parents.

2INT : Mungkin ada yang telah menikah di umur 20 an atau 30an

3PR : And I still remember the iklan the guys in Indonesia are like "kapan

kawin". (audience laughing)

4INT : Dan seperti iklan aa kapan kawin.

5PR : But it doesn't matter if you're under 18 or over 18 if you're still with your parents. It's a command from God -- to obey your parents. 
6INT : Jadi tidak masalah apakah umur 18 diatas ada yang 1830 jika masih tinggal dengan orang tua harus mengikuti orang tua yaitu taatilah orang tuamu.

In the above data the bold quotation delivered by the interpreter. In tur 1, the preacher said "Some people feel like they are aa late getting married. They're in after their twenties and thirties still living with their parents" which was rendered by the interpreter in turn 2 into mungkin ada yang telah menikah di umur dua puluh atau tiga puluhaan. By comparing the interpreter's rendition in turn 1 and turn 2, the speaker conveyed number "twenties or thirties" and it was clearly seen that the interpreter strives to accurately delivered by the in interpreter into "dua puluh atau tiga puluhan"clearly and correctly. In turn 5 the speaker continues conveyed number "under 18 or over 18 " which was then rendered by the interpreter in turn 6 into "umur 18 diatas ada yang18 30" based on the example.

\section{Conclusion}

Based on the analysis, in performing interpreting in Gereja Kristus Yesus Kuta Bali, the modes applied by the interpreter was consecutive mode where by the interpreter speaks after the source language speaks, each segment is short, enough to memorize, each segment is short, relying on text structure, without note taking, or any required equipment. Based on the setting, where the interpreting took place, in this study the setting was community interpreting because the interpreter work in the field of religious service. The interpreting strategies applied in interpreting the sermon by the interpreters at Gereja Kristus Yesus were preparation strategies, complex syntax, word order, general adverbial clauses, untranslatability, figures of speech, argumentation, transposition, humor, and numbers.

\section{Acknowledgements}

I would like to dedicate my deepest gratitude to my supervisor lectures for their critical review and to my family, brothers, and sisters for their endless loves, supports, and prayers.

\section{References}

Baker, Mona.1992. In Other Words, a Course book on Translation. London and USA. Routledge Nolan, James. 2005. Public Service Interpreting, Texas: Linguistic Services Houston

Pöchhacker Franz.2004. Introducing Interpreting Studies. London and New York:Routledge Taylor \& Francis Group

Russell, Debra.2004. Interpreting Strategies in Legal Discourse. International Conference Critical Link 4. Stockholm, Sweden.

Vennuti, Lawrence, (ed)2000. Tre translation Studies Reader. London. 